\title{
Retirement of the Editorial Board Member of JCSHM Dr. Toshiyuki Oshima, Professor Emeritus of Kitami Institute of Technology (KIT), Japan
}

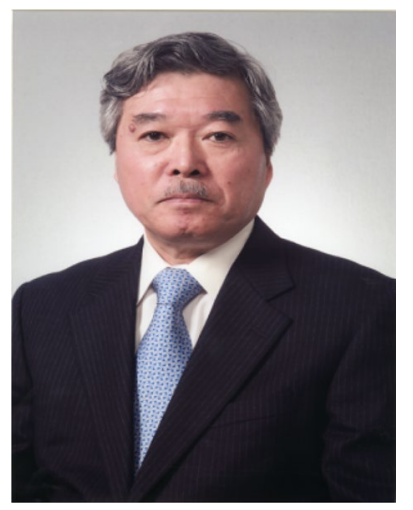

I wanted to bring the bittersweet news of Professor Toshiyuki Oshima's retirement from the journal after 11 years of dedicated service to JCSHM. From the beginning, Professor Oshima focused on strengthening the contents of the journal. He worked tirelessly in engaging the reviewers, interacting with other members of the editorial board and helping the authors to achieve excellence. I am also happy for him, since he will have more time to spend with family and friends. I am also providing a synopsis of Professor Oshima's academic and professional achievements in the following paragraphs.

Professor Oshima's primary area of expertise pertain to structural engineering with particular emphasis in dynamics of structures, condition monitoring, structural health monitoring, and non-destructive testing of bridges. He received his BS, MS, and PhD degrees all in civil engineering, from Hokkaido University, Muroran Institute of Technology, and Hokkaido University in Japan, respectively. Dr. Oshima began his academic career as a lecturer at Kitami Institute of Technology in 1974. Over a period of 47 years at KIT, Dr. Oshima served the university at various capacities, as professor, director of cooperative research, and as the vice president of KIT during the period 2004-2007. Dr. Oshima is now, professor emeritus at KIT.

Professor Oshima has been a member of ISHMII, since its inception, an active member of ISHMII council, and a member of JCSHM's editorial board. In addition, he has been involved in the development of standards at ISO, served as chair of the committees for dynamic tests of bridges, and evaluation of measurement results. In addition to the editorial board activities, Professor Oshima has served ISHMII in many ways, including organization of ISHMII workshop in 2003. He received ISHMII's prestigious Aftab Mufti medal in 2013, and honorary member of JSCE since 2017. Professor Oshima has published extensively on the subject of civil structural health monitoring and consulted on major bridge evaluation projects across the globe.

Personally, I will miss the insights and warm collaborative spirit of Professor Oshima in working together. Please join me in congratulating Professor Oshima for his extraordinary service to JCSHM.

Farhad Ansari,

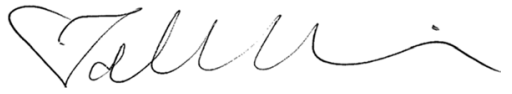

Editor-in-Chief

January 17,2022

Publisher's Note Springer Nature remains neutral with regard to jurisdictional claims in published maps and institutional affiliations. 